\title{
Pelatihan dan Penyuluhan Pemanfaatan Teknologi Informasi Untuk Peningkatan SDM pada Usaha Kopi Jelijih Punggang Tabanan
}

\author{
* Ni Kadek Sumiari, Made Pradnyana Ambara \\ Fakultas Informatika dan Komputer Institut Teknologi dan Bisnis STIKOM Bali \\ Jln Raya Puputan No 86 Denpasar \\ *E-mail : sumiari@stikom-bali.ac.id \\ DOI: https://doi.org/10.21107/pangabdhi.v6i2.7553 \\ Naskah diterima 15 Juni 2020, Revisi 27 Juli 2020, Terbit 29 Oktober 2020
}

\begin{abstract}
Abstrak
Kopi merupakan salah satu komoditas unggulan perkebunan di Provinsi Bali. Salah satu daerah penghasil kopi di Bali adalah desa Jelijih Punggang yang terletak di kecamatan Pupuan Kabupaten Tabanan. Bapak I Nyoman Segel merupakan salah satu petani kopi yang berasal dari desa Jelijih Punggang yang merupakan mitra dalam kegiatan ini. Mitra memiliki perkebunan kopi seluas 50 are dengan hasil panen kopi 2-3 ton setiap tahun. Panen dilakukan oleh mitra sendiri dan dibantu anggota keluarga dengan menggunakan alat panen yang sederhana dan jumlahnya terbatas sehingga memerlukan waktu lama dalam proses panen. Penjualan hasil panen juga belum dilakukan pencatatan oleh mitra sehingga mitra tidak bisa mengetahui secara pasti penghasilan dan keuntungannya. Hal ini dikarenakan mitra belum memahami tentang pentingnya pencatatan penghasilan/keuangan dan juga mitra belum memanfaatkan teknologi informasi yang dimiliki dalam melakukan pencatatan keuangan. Permasalahan lainnya yang dihadapi oleh mitra adalah selama 15 tahun mitra belum memiliki identitas/nama usaha. Mitra belum memahami pentingnya identitas usaha. Untuk mengatasi permasalahan yang dialami oleh mitra maka diberikan solusi berupa (1) pemberian alat bantu panen; (2) penyuluhan pentingnya pencatatan keuangan; (3) pelatihan pencatatan keuangan dengan menggunakan aplikasi berbasis android "catatan keuangan"; (4) penyuluhan pentingnya identitas usaha serta (5) pembuatan desain identitas usaha berupa desain logo, desain kemasan dan kartu nama.
\end{abstract}

Kata Kunci: kopi, Tabanan, teknologi informasi, identitas usaha

\begin{abstract}
Coffee is one of the prime commodities in the province of Bali. One of the coffee-producing areas in Bali is Jelijih Punggang village, in the Pupuan sub-district, Tabanan district. Mr. I Nyoman Segel is one of the coffee farmers from the village of Jelijih Punggang who is a partner in this activity. Mr. I Nyoman Segel owns a 50acre coffee plantation with 2-3 tons of coffee yield every year. Harvesting is done by the partners themselves and assisted by family members using simple harvesting tools and the amount is limited so it requires a long time in the harvest process. Harvest sales have also not been recorded by partners, so partners cannot know what their income and profits are. This is because partners do not yet understand the importance of recording income/finances and partners have not used the information technology they have in carrying out financial records. Another problem faced by partners is that for 15 years the partner has not had an identity/business name. Partners do not yet understand the importance of business identity. To overcome the problems experienced by partners, solutions were provided in the form of (1) provision of harvesting tools; (2) counseling on the importance of financial records; (3) training in financial records using an android application based on "financial records"; (4) counseling on the importance of business identity and, (5) business identity design in the form of logo design, packaging design, and business cards.
\end{abstract}

Keywords: Coffee, Tabanan, information technology, corporate identity

\section{PENDAHULUAN}

Kopi merupakan salah satu komoditas unggulan perkebunan di Provinsi Bali dengan total produksi kopi pada tahun 2018 adalah sebanyak 4.217 ton untuk kopi arabika dan 11.439 ton untuk kopi robusta. Salah satu
Kabupaten di Bali yang merupakan penghasil kopi terbesar adalah Kabupaten Tabanan dengan luas perkebunan kopi 10,494.65 Ha di tahun 2018. Kecamatan Pupuan merupakan kecamatan yang memiliki perkebunan kopi terluas di Kabupaten Tabanan dengan luas lahan 7,850.97 
Ha serta menghasilkan kopi sebanyak 5,178.26 ton. Perkebunan Kopi di kecamatan Pupuan tersebar di 14 desa dan salah satunya adalah di desa Jelijih Punggang yang memiliki 412,2 ha lahan perkebunan kopi.

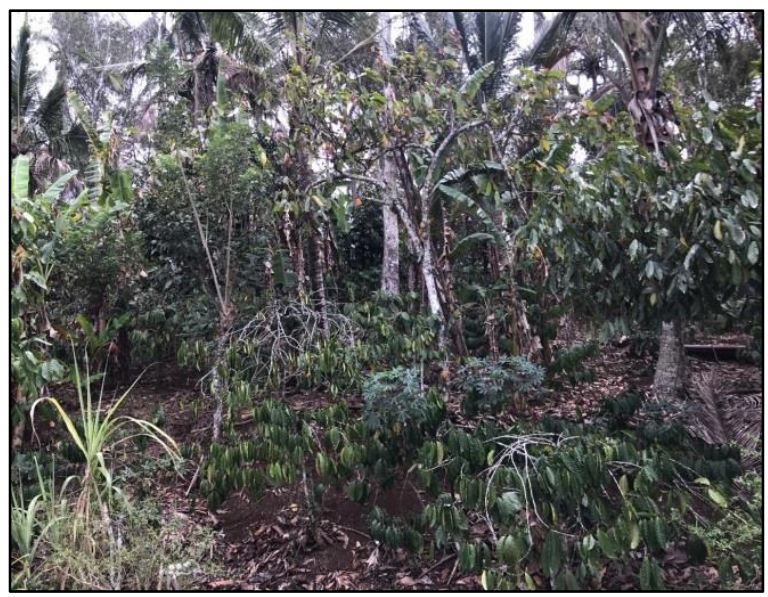

Gambar 1. Kondisi Kebun Mitra
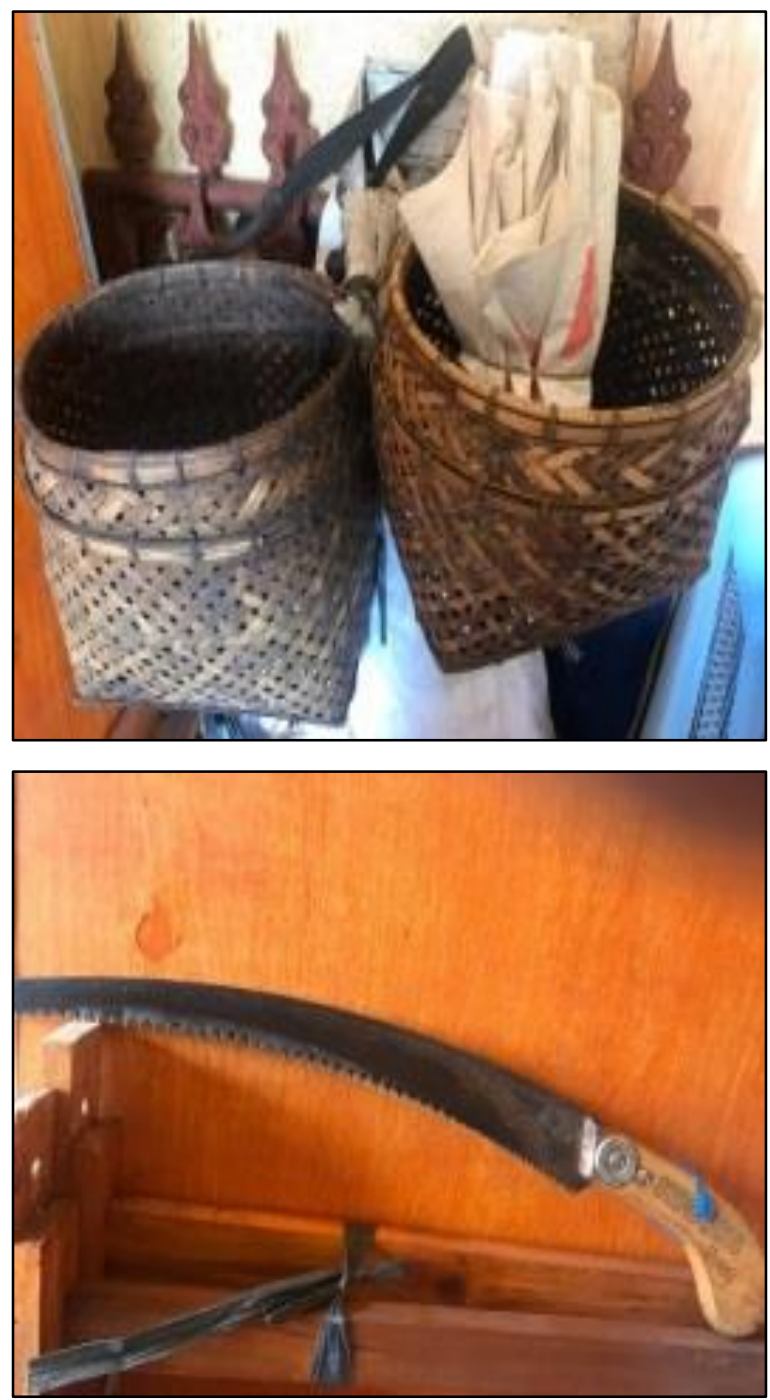

Gambar 2 Alat Untuk Memanen Kopi
Bapak I Nyoman Segel merupakan salah satu petani kopi di desa Jelijih Punggang yang merupakan mitra dalam Program Kemitraan Masyarakat ini. Bapak I Nyoman Segel berprofesi sebagai petani kopi kurang lebih sejak 15 tahun lalu dan memiliki lahan perkebuanan kopi seluas 50 are dengan hasil panen 1-2 ton setiap tahun. Produk yang dihasilkan oleh mitra adalah biji kopi dari hasil panen perkebunan yang dimiliki. Dalam menjalankan usahanya Bapak I Nyoman Segel juga dibantu oleh putranya yaitu saudara Purnayasa.

Selama ini panen kopi dilakukan oleh mitra sendiri dibantu oleh anggota keluarga dan beberapa pekerja yang berasal dari warga sekitar dengan menggunakan alat-alat yang masih sederhana dengan jumlah terbatas. Mitra menggunakan keranjang sebagai media untuk menampung hasil panen dengan jumlah yang juga terbatas. Proses panen mitra memerlukan waktu rata-rata 20 hari dengan jumlah total pekerja 6 orang dan alat panen berupa pisau panjang 3 buah dan keranjang 2 buah. Keterbatasan jumlah keranjang dan alat panen menyebabkan beberapa orang pekerja memetik kopi dengan tanpa menggunakan alat bantu panen sehingga mitra memerlukan waktu yang lama dalam proses panen

Panen yang dihasilkan oleh mitra dijual dalam bentuk biji kopi. Selama ini mitra belum melakukan pencatatan hasil panen dan pencatatan penjualan sehingga mitra tidak dapat mengetahui keuntungan yang diperoleh secara pasti. Hal ini dikarenakan mitra belum memahami pentingnya pencatatan keuangan. Penting sekali bagi pemilik usaha untuk dapat membaca dan menafsirkan informasi keuangan. Paling tidak, setiap pemilik usaha dapat menghitung untung ruginya, akan tetapi yang paling penting untuk dapat memahami makna untung atau rugi bagi usahanya. Selain itu mitra juga belum memanfaatkan teknologi informasi dalam pencatatan keuangan, padahal mitra yang dalam hal ini putranya memiliki fasilitas yang dapat digunakan untuk melakukan pencatatan keuangan berupa smartphone. Saudara Purnayasa sebagai putra dari mitra memiliki pemahaman dalam menggunakan perangkat smartphone, sehingga akan lebih baik apabila mitra dapat memanfaatkan fasilitas yang telah dimiliki untuk melakukan pencatatan keuangan.

Permasalahan lain dari mitra adalah selama 15 tahun mitra belum memiliki identitas usaha. Dalam penjualan produk mitra hanya dikemas 
menggunakan karung beras tanpa identitas usaha. Ini disebabkan karena mitra belum memahami tentang pentingnya identitas usaha. Padahal tujuan dari identitas usaha adalah agar usaha mudah dikenali oleh semua pihak. Selain digunakan untuk membedakan identitas perusahaan yang satu dengan identitas yang lain. Identitas usaha bisa menciptakan kesan utama yang positif dan diharapkan dapat berlangsung secara konsisten.

Berdasarkan analisis situasi tersebut maka melalui Program Kemitraan Masyarakat, pengusul yang merupakan tim dosen dan mahasiswa ITB STIKOM Bali ingin membantu meningkatkan sumber daya manusia pada usaha kopi di Desa Jelijih Punggang melalui pemanfaatan teknologi informasi

\section{METODE}

Lokasi PKM terletak di Br. Punggang, Desa Jelijih Punggang Kecamatan Pupuan Kabupaten Tabanan. Jarak ITB STIKOM Bali ke lokasi PKM adalah $40 \mathrm{~km}$ apabila ditarik garis langsung melalui map situs e-research dan $71.2 \mathrm{~km}$ apabila mengikuti rute google map. Perjalanan ke lokasi mitra bisa ditempuh dalam waktu 2 hingga 2.5 jam melalui jalur Denpasar-Gilimanuk

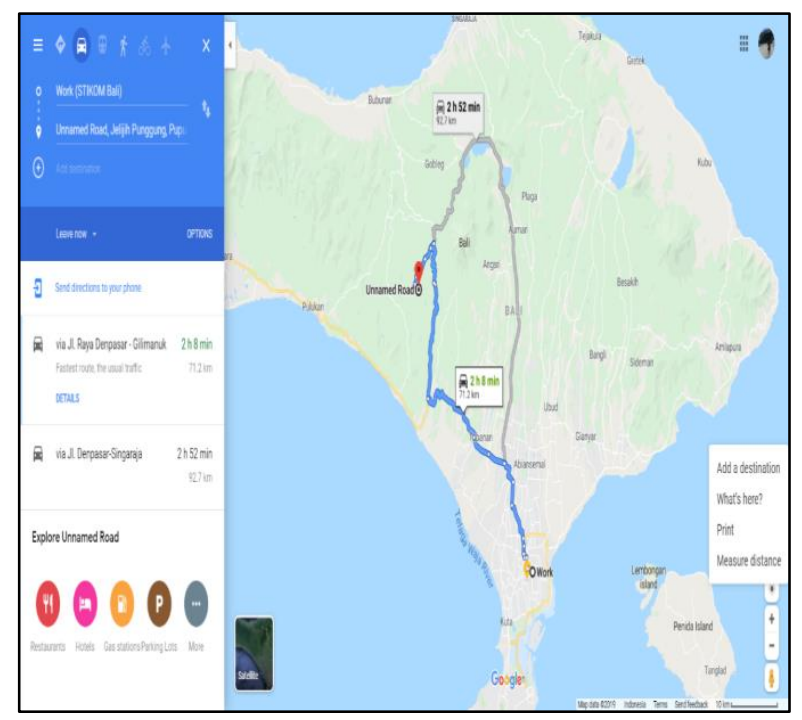

Gambar 3. Lokasi Mitra

Melalui kegiatan pengabdian masyarakat pelatihan dan penyuluhan ini akan ditawarkan solusi bagi permasalahan-permasalahan yang telah dirumuskan di atas. Metode yang digunakan dalam pengabdian masyarakat ini adalah model pemberdayaan sumber daya manusia dengan menerapkan tujuh (7) tahapan kegiatan seperti dalam gambar berikut:

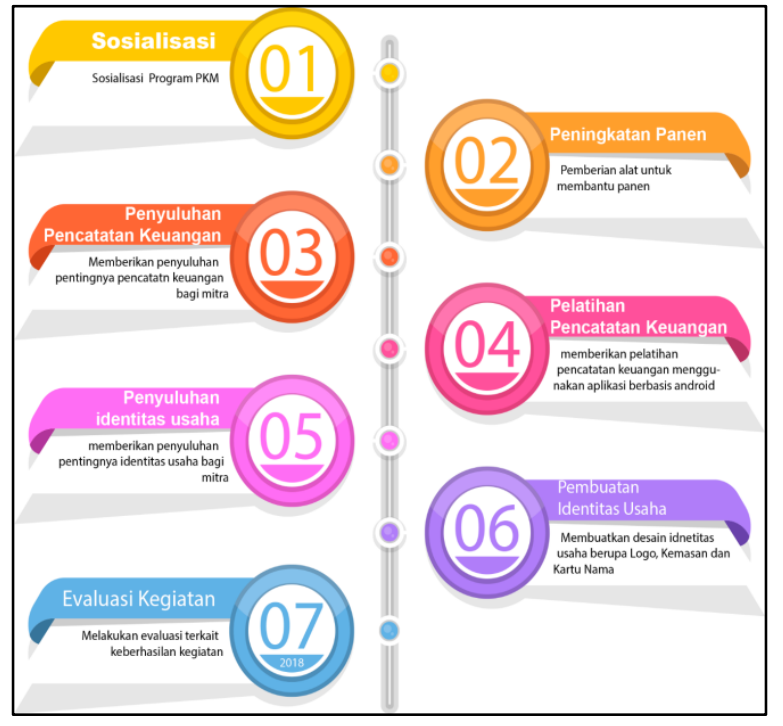

Gambar 4. Metode Pelaksanaan Kegiatan

1. Kegiatan pertama adalah sosialisasi kegiatan. Dalam kegiatan sosialisasi disampaikan tujuan kegiatan serta sasaran kegiatan pengabdian masyarakat kepada mitra. Selain itu juga dilakukan pencatatan visualisasi dalam bentuk foto dan video

2. Kegiatan kedua yaitu pemberian alat bantu panen bagi mitra sehingga bisa mempercepat proses panen. Alat yang diberikan berupa gunting dahan dan keranjang. Penyerahan alat dilakukan oleh Tim Pelaksana dan diserahkan kepada pemilik yaitu Bapak I Nyoman segel.

3. Kegiatan ketiga adalah penyuluhan pentingnya pencatatan keuangan bagi mitra sehingga mitra memahami tentang pentingnya pencatatan keuangan serta pengetahuan mitra tentang pencatatan keuangan meningkat. Penyuluhan akan diberikan oleh pakar yang memahami tentang pencatatan keuangan. Peserta dalam penyuluhan ini adalah pemilik Bapak I Nyoman Segel serta anggota keluarga mitra.

4. Kegiatan keempat yaitu pelatihan pencatatan keuangan dengan memanfaatkan teknologi informasi. Dalam kegiatan ini mitra akan diberikan pelatihan pencatatan keuangan dengan menggunakan aplikasi berbasis adroid "catatan keuangan" yang bisa di unduh di google playstore. Pelatihan akan diberikan oleh Tim pelaksana yang memiliki kompetensi di bidang Teknologi infromasi. Peserta pelatihan adalah Putra dari pemilik yaitu saudara Purnayasa yang memiliki kemampuan dalam mengoperasikan smartphone. 
5. Kegiatan kelima yaitu penyuluhan pentingnya identitas usaha bagi mitra. Pada kegiatan ini mitra akan diberikan pengetahuan dan pemahaman tentang identitas usaha serta ide untuk nama usaha. Kegiatan ini akan diberikan oleh tim pelaksana kepada pemilik yaitu I Bapak Nyoman Segel, serta anggota keluarga mitra.

6. Kegiatan keenam adalah pembuatan desain identitas usaha berupa logo, desain kemasan dan kartu nama bagi mitra. Pada kegiatan ini desain akan diuatkan oleh designer dimana ide untuk bentuk dan warna logo akan didiskusikan dengan mitra serta dibantu Tim pelaksana. Hasil dari kegiatan ini berupa desain logo, desain kemasan, kartu nama usaha bagi mitra serta kemasan berupa karung beras yang sudah di sablon dengan desain kemasan.

7. Kegiatan evaluasi yang dilakukan yaitu kegiatan evaluasi untuk mengukur peningkatan sumber daya manusia dengan menggunakan instrument kuesioner yang akan dilakukan di seluruh kegiatan penyuluhan dan pelatihan. Evaluasi terhadap seluruh kegiatan juga akan dilakukan pada akhir kegiatan Program Kemitraan Masyarakat (PKM).

\section{HASIL DAN PEMBAHASAN}

Kegiatan pengabdian masyarakat ini dilaksanakan selama 8 bulan, yaitu dari bulan November 2019 hingga bulan Juni 2020. Pada bulan awal kegiatan dilakukan secara tatap muka. Adapun kegiatan yang dilakukan pada tahap pertama terdapat tiga kegiatan yaitu sosialisasi kegiatan pengabdian masyarakat, penyerahan alat bantu produksi, dan penyuluhan pentingnya pencatatan keuangan. Pada kegiatan tahap kedua dilakukan secara daring. Hal ini dikarenakan terdapatnya pandemi virus covid 19 dimana pemerintah mengeluarkan peraturan untuk pembatasan kegiatan masyarakat. Pada tahap kedua ini juga dilakukan tiga kegiatan yaitu pelatihan aplikasi pencatatan keuangan, penyuluhan pentingnya identitas usaha, serta pembuatan desain identitas usaha.

Sesuai dengan rencana kegiatan yang telah ditentukan, pada tahap pertama kegiatan pengabdian masyarakat ini telah dilakukan 6 (enam) kegiatan selama 8 bulan. Kegiatan yang telah dilakukan dijabarkan sebagai berikut:

\section{Sosialisasi Kegiatan}

Pada awal kegiatan dilakukan sosialisasi kegiatan pengabdian masyarakat ke mitra UMKM. Sosialisasi kegiatan pengabdian masyarakat diberikan oleh ketua pelaksana dan anggota dengan peserta adalah pemiliki dari UMKM bapak I Nyoman Segel dan Agus Purnayasa. Materi yang diberikan pada kegiatan ini dilakukan secara lisan yaitu penyampaian tujuan dari kegiatan, mekanisme kegiatan pengabdian serta diskusi penentuan jadwal/agenda kegiatan selanjutnya yang akan dilakukan dengan UMKM.

\section{Penyerahan Alat}

Berdasarkan permasalahan yang dialami mitra yaitu jumlah peralatan yang dimiliki masih terbatas sehingga proses panen memerlukan waktu yang lama, maka pada kegiatan kedua dalam pengamdian masyarakat ini dilakukan penyerahan alat ke UMKM. Alat yang diserahkan pada tahap pertama kegiatan ini yaitu tiga (3) buah gunting dahan serta satu (1) buah Gergaji Kopi. Kegiatan ini dilakukan oleh Ketua pelaksana serta Anggota Pelaksana. Anggota mahasiswa dalam kegiatan ini berperan membantu dalam pembelian alat yang akan diberikan.
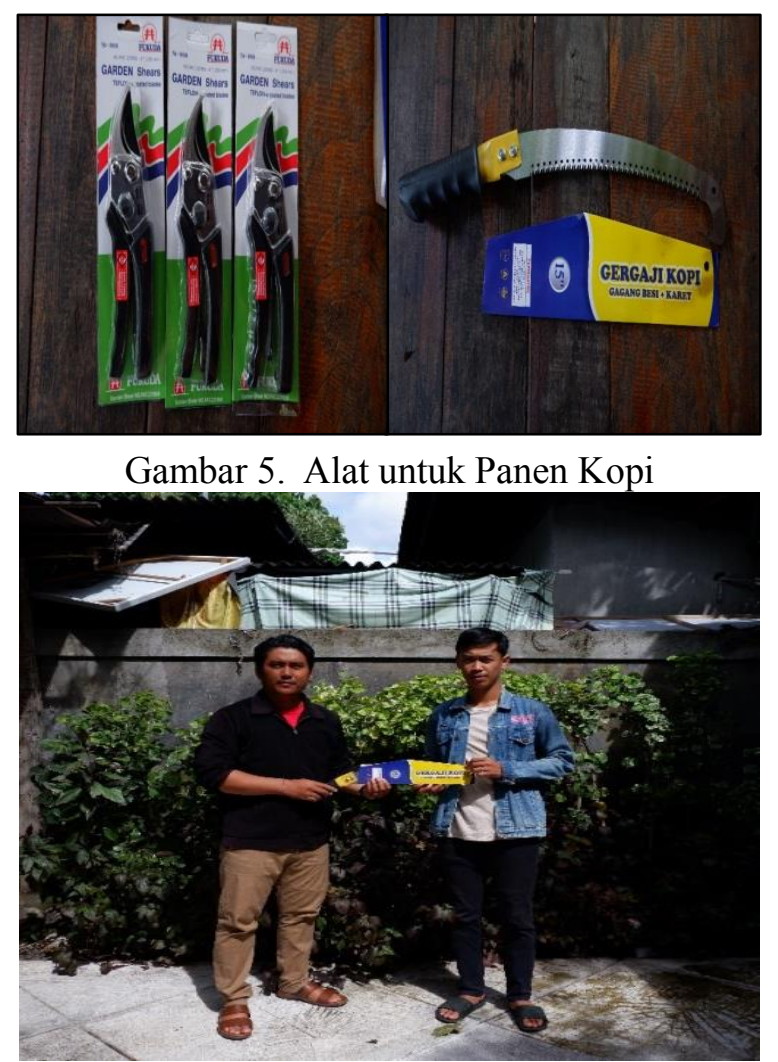

Gambar 6. Pemberian Bantuan Alat Panen Kopi 


\section{Penyuluhan Pencatatan Keuangan.}

Kegiatan ketiga pada pelaksanaan tahap pertama pengabdian masyarakat ini adalah penyuluhan pentingnya pencatatan keuangan bagi mitra. Kegiatan ini merujuk pada permasalahan yang dialami oleh mitra yaitu mitra belum memiliki pencatatan keuangan serta belum memahami tentang pencatan keuangan. Sebelum kegiatan penyuluhan dilakukan pengukuran pemahaman mitra tentang pencatatan keuangan menggunakan metode wawancara dengan menjawab beberapa pertanyaan yang diberikan. Metode wawancara digunakan karena peserta pelatihan hanya berjumlah 2 orang sehingga tidak memungkinkan pengukuran menggunakan kuesioner.

Dari hasil wawancara diperoleh bahwa mitra belum memahami tentang pencatatan keuangan. Penyuluhan tentang pentingnya pencatatan keuangan diberikan oleh pakar di bidang akuntansi. Materi yang diberikan berupa pemahaman tentang pencatatan keuangan sederhana serta cara membuat catatan keuangan sederhana menggunakan buku kas. Peserta pelatihan adalah dari UMKM Agus Purnayasa yang nantinya akan bertugas mencatat keuangan dari UMKM.

\begin{tabular}{|l|l|l|l|l|c|}
\hline \multirow{2}{*}{ Tanggal } & \multicolumn{2}{|c|}{ Uang Masuk } & \multicolumn{2}{c|}{ Uang Keluar } & \multirow{2}{*}{ Saldo } \\
\cline { 2 - 5 } & Keterangan & Jumlah & Keterangan & Jumlah & \\
\hline $1 / 5$ & Kas Awal & 500.000 & & & 500.000 \\
\hline $1 / 5$ & Pinjaman Bank & 2.000 .000 & & & 2.500 .000 \\
\hline $3 / 5$ & & & Ongkos Ke pasar & 50.000 & 2.450 .000 \\
\hline & & & $\begin{array}{l}\text { Membeli bibit dan } \\
\text { pupuk }\end{array}$ & 200.000 & 2.250 .000 \\
\hline $4 / 5$ & Menjual Kopi & 100.000 & & & 2.350 .000 \\
\hline $5 / 5$ & & & Membeli Pupuk & 300.000 & 2.050 .000 \\
\hline $10 / 5$ & Jual Cengkeh & 150.000 & & & 2.200 .000 \\
\hline $10 / 5$ & Jual hasil panen & 250.000 & & & 2.450 .000 \\
\hline $11 / 5$ & Hibah & 1.000 .000 & & & 3.450 .000 \\
\hline
\end{tabular}

Gambar 7. Contoh pencatatan keuangan UMKM

\section{Pelatihan Pencatatan Keuangan}

Kegiatan ini merupakan lanjutan dari kegiatan sebelumnya yaitu kegiatan penyuluhan pentingnya pencatatan keuangan bagi UKM. Pada kegiatan ini dilakukan pelatihan pencatatan keuangan menggunakan aplikasi pencatatan keuangan yang bisa diunduh di Play store. Dikarenakan karena kondisi sedang dalam masa pandemic maka kegiatan dilakukan secara daring menggunakan aplikasi Zoom. Peserta dari kegiatan ini adalah 1 orang yaitu saudara agus
Purnayasa yang merupakan anggota dari UKM yang memahami cara penggunaan teknologi informasi. Pelatihan ini diberikan oleh ketua pelaksana dan juga anggota pelaksana serta dibantu oleh dua orang mahasiswa. Hasil dari kegiatan ini adalah UMKM memiliki pencatatan keuangan yang memanfaatkan teknologi informasi yakni menggunakan Smartphone sehingga pencatatan keuangan bisa dilakukan dimana saja dan kapan saja. Pada kegiatan ini terdapat beberapa kendala yaitu jaringan seluler dari Mitra dan juga dari beberapa anggota pelaksana yang kurang baik sehingga untuk melakukan kegiatan video conference dengan live video agak sedikit bermasalah sering terjadi lag dan putus koneksi.

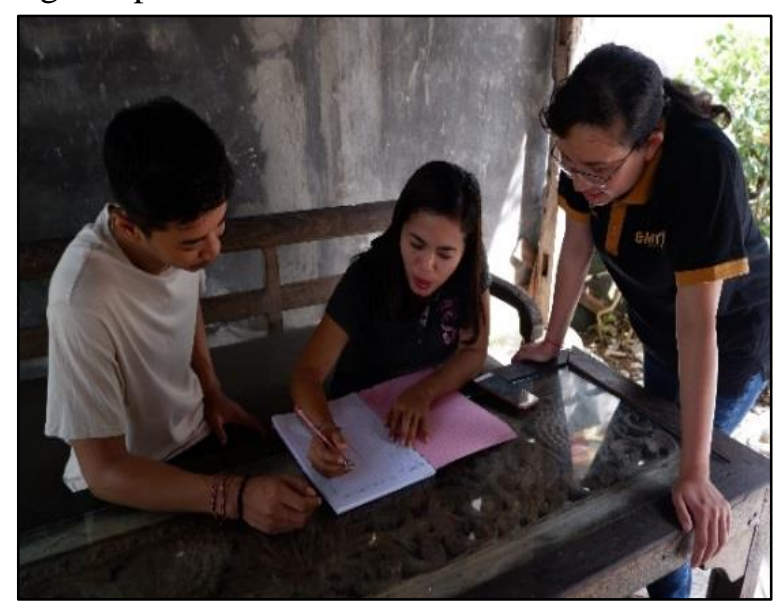

Gambar 8. Pelatihan Pencatatan Keuangan Sederhana

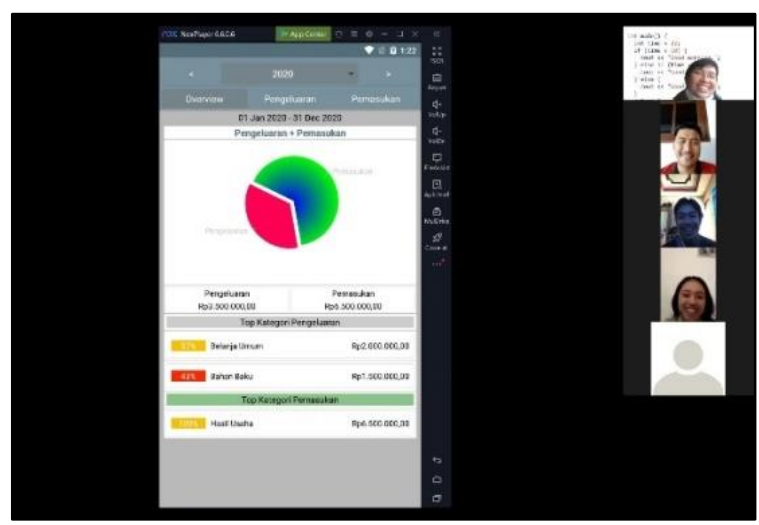

Gambar 9. Pelatihan Secara Daring

\section{Penyuluhan Pentingnya Identitas Usaha}

Pada kegiatan ini dilakukan penyuluhan tentang pentingnya identitas usaha bagi UMKM. Kegiatan ini untuk mengatasi permasalahan Mitra yang belum memiliki identitas usaha karena belum memahami pentingnya identitas usaha. Pada kegiatan ini Mitra diberikan pemahaman tentang pentingnya identitas usaha serta dilakukan diskusi mengenai identitas usaha 
yang akan digunakan oleh Mitra, seperti penamaan dari usaha. Kegiatan ini dilaksanakan secara daring menggunakan aplikasi Zoom karena situasi pandemik yang masih belum memungkinkan untuk berkunjung ke tempat Mitra. Kegiatan diberikan oleh anggota pelaksana yang dibantu oleh ketua pelaksana serta 2 orang mahasiswa. Mengingat dari kegiatan sebelumnya yang juga dilakukan secara daring dimana terjadi masalah pada koneksi, maka pada kegiatan ini live video dari peserta dimatikan dengan begitu kegiatan jadi terlaksana dengan baik.

\section{Pembuatan Identitas Usaha}

Setelah pada kegiatan sebelumnya telah diberikan pemahaman tentang identitas usaha, juga telah dilakukan diskusi mengenai identitas usaha yang akan digunakan oleh Mitra. Pada kegiatan ini dilakukan pembuatan dan penyerahan identitas usaha bagi mitra. Kegiatan ini dilakukan secara daring menggunakan aplikasi Zoom. Pada kegiatan ini mitra diberikan soft copy file identitas usaha yang telah dibuat. Soft copy file yang diserahkan sudah sesuai dengan permintaan dari Mitra. Desain usaha yang diberikan berupa logo, desain brosur, desain kartu nama, serta contoh pengaplikasian desain pada barang-barang tertentu seperti tas, gelas, apron, dan sebagainya.

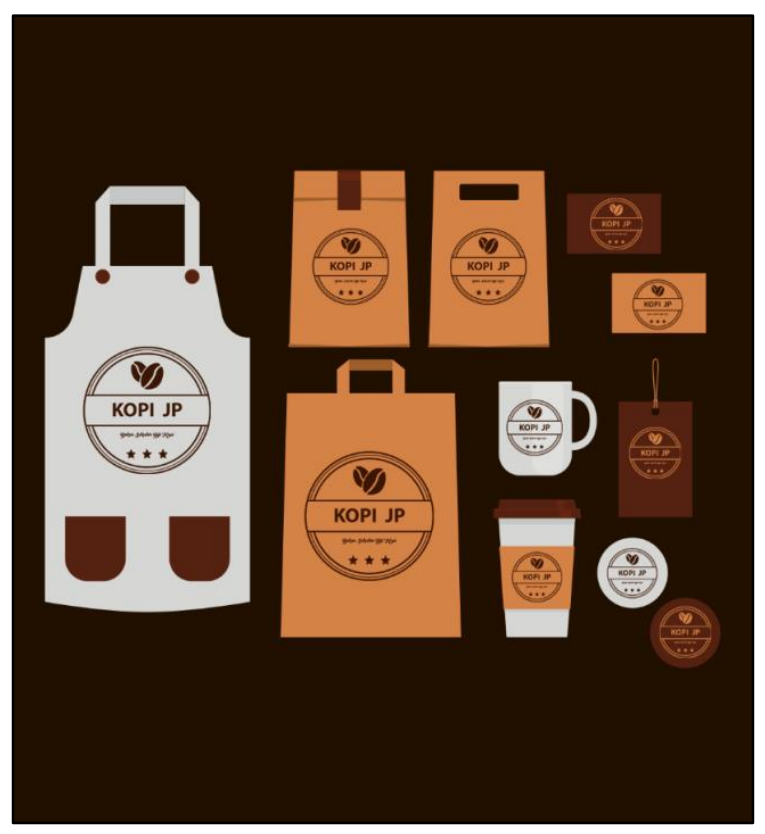

Gambar 10. Contoh pengaplikasian logo

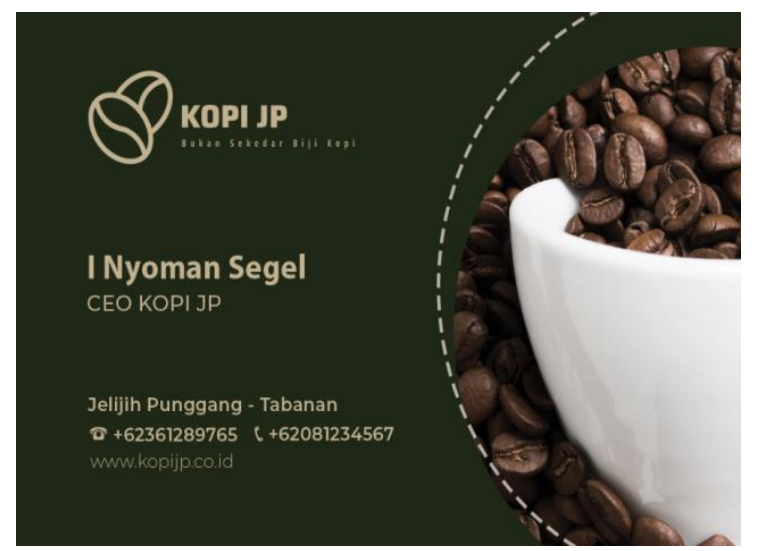

Gambar 11. Desain Kartu Nama Usaha

\section{Evaluasi Kegiatan}

Pada kegiatan pengabdian masyarakat ini dilakukan beberapa kali evaluasi menggunakan metode wawancara dikarenakan peserta pelatihan hanya satu orang. Evaluasi dilakukan dua kali pada kegiatan penyuluhan pencatatan keuangan yaitu sebelum penyuluhan serta setelah penyuluhan. Pada saat sebelum penyuluhan dilakukan mitra diberikan beberapa pertanyaan tentang pemahaman pencatatan keuangan. Hasil wawancara tersebut adalah mitra belum memiliki pencatatan keuangan untuk usahanya, mitra tidak mengetahui secara pasti keuntungan, mitra tidak mengetahui dan mencatat pengeluaran serta pemasukan serta mitra tidak memiliki media/alat khusus untuk mencatat keuangan. Evaluasi juga dilakukan setelah kegiatan penyuluhan, dimana peserta diberikan beberapa pertanyaan mengenai pelatihan yang telah diikuti. Dari hasil evaluasi mitra menyatakan bahwa pelatihan sudah baik, materi yang disampaikan sesuai dengan kebutuhan mitra, penyampaian materi mudah dimengerti serta mudah di praktekan. Hasil evaluasi dari keseluruhan kegiatan berdasarkan kuesioner yang sudah disebarkan ke Mitra hasil kegiatan berjalan dengan cukup baik akan tetapi dikarenakan adanya pandemi covid 19 beberapa kegiatan yang harusnya dilakukan dengan tatap muka dilakukan secara daring. Hal ini menyulitkan Mitra karena bermasalah dengan koneksi jaringan. Lokasi Mitra yang letaknya ada di desa pedalaman menyebabkan koneksi pada daerah tersebut tidak begitu bagus. Sehingga pada saat kegiatan secara daring berlangsung sering terjadi putus koneksi, ini menyebabkan durasi kegiatan menjadi lebih lama. 
Tabel 1. Target dan Capaian Kegiatan

\begin{tabular}{|l|l|l|l|l|}
\hline No & Kegiatan & Target Luaran & Indikator Capaian & Capaian \\
\hline 1 & Penyerahan Alat & $\begin{array}{l}\text { Peningkatan Jumlah } \\
\text { Aset }\end{array}$ & $\begin{array}{l}\text { Aset alat yang } \\
\text { dimiliki mitra } \\
\text { bertambah }\end{array}$ & $\begin{array}{l}\text { Mitra memiliki } \\
\text { penambahan asset } \\
\text { baru yaitu berupa } \\
\text { gunting dahan dan } \\
\text { gergaji kopi. }\end{array}$ \\
\hline 2 & $\begin{array}{l}\text { Penyuluhan Pencatatan } \\
\text { Keuangan }\end{array}$ & $\begin{array}{l}\text { Peningkatan } \\
\text { Pemahaman Pencatatan } \\
\text { Keuangan UKM } \\
\text { dan memiliki } \\
\text { pencatatan } \\
\text { keuangan manual }\end{array}$ & $\begin{array}{l}\text { Satu orang anggota } \\
\text { mitra sudah } \\
\text { berhasil melakukan } \\
\text { pencatatan } \\
\text { keuangan } \\
\text { menggunakan buku } \\
\text { kas }\end{array}$ \\
\hline 3 & $\begin{array}{l}\text { Pelatihan Pencatatan } \\
\text { Keuangan }\end{array}$ & $\begin{array}{l}\text { Mitra memiliki aplikasi } \\
\text { untuk melakukan } \\
\text { pencatatn keuangan }\end{array}$ & $\begin{array}{l}\text { Mitra memiliki } \\
\text { pencatatan } \\
\text { keuangan dengan } \\
\text { memanfaatkan } \\
\text { teknologi informasi }\end{array}$ & $\begin{array}{l}\text { Satu orang anggota } \\
\text { mitra memahami } \\
\text { cara penggunaan } \\
\text { aplikasi pencatatan } \\
\text { keuangan }\end{array}$ \\
\hline 4 & $\begin{array}{l}\text { Penyuluhan Pentingnya } \\
\text { Identitas Usaha dan } \\
\text { pembuatan identitas usaha }\end{array}$ & $\begin{array}{l}\text { Peningkatan } \\
\text { pemahaman mitra } \\
\text { tentang identitas usaha } \\
\text { dan memiliki desain } \\
\text { identitas usaha }\end{array}$ & $\begin{array}{l}\text { Mitra memiliki } \\
\text { identitas usaha } \\
\text { berupa desain logo, } \\
\text { brosur, kartu nama, } \\
\text { serta desain } \\
\text { penggunaan logo. }\end{array}$ \\
\hline
\end{tabular}

\section{KESIMPULAN}

Berdasarkan kegiatan pengabdian masyarakat yang telah dilakukan maka dapat diperoleh kesimpulan sebagai berikut:

1. Aset yang dimiliki mitra meningkat yaitu mitra memiliki alat bantu panen berupa gunting dahan serta gergaji kopi

2. Mitra memahami tentang pentingnya pencatatan keuangan

3. Mitra memiliki buku pencatatan keuangan sederhana

4. Mitra memiliki aplikasi berbasis android untuk melakukan pencatatan keuangan.

5. Mitra memahami tentang pentingnya identitas usaha serta memiliki desain identitas usaha

Saran yang dapat diberikan untuk kegiatan selanjutnya adalah kan ada kegiatan berupa pelatihan media pemasaran secara daring dengan memanfaatkan media sosial ataupun media berbasis teknologi informasi lainnya. Kegiatan ini tentunya akan sangat membantu Mitra di mana pada masa "New Normal Life" usaha perdagangan disarankan dilakukan secara daring.

\section{UCAPAN TERIMAKASIH}

Ucapan terima kasih yang sedalam-dalam nya Kepada Institusi ITB STIKOM Bali serta semua pihak yang telah memberikan kesempatan dan medukung dalam pelaksanaan pengabdian masyarakat ini.

\section{DAFTAR PUSTAKA}

Badan Pusat Statistik Provinsi Bali. 2019. Produksi Kopi Arabika Menurut Kabupaten/Kota di Provinsi Bali 2000-2018. https://bali.bps.go.id/dynamictable/2019/10/1 8/195/produksi-kopi-arabika-menurutkabupaten-kota-di-provinsi-bali-2000-2018.

Badan Pusat Statistik Provinsi Bali. 2019. Produksi Kopi Robusta Menurut Kabupaten/Kota di Provinsi Bali 2000-2018. https://bali.bps.go.id/dynamictable/2019/10/1 8/196/produksi-kopi-robusta-menurutkabupaten-kota-di-provinsi-bali-2000-2018.

Badan Pusat Statistik Kabupaten Tabanan. 2018. "Kabupaten Tabanan Dalam Angka 2018," Tabanan, 2018. [Online]. Available: https://tabanankab.bps.go.id/publication/down $\underline{\text { load.html }}$

Badan Pusat Statistik Kabupaten Tabanan. 2018. Kecamatan Pupuan Dalam Angka. Tabanan, 2018. [Online]. Available: https://tabanankab.bps.go.id/publication/down load.html?

Ediraras, D.T. 2010. Akuntansi dan Kinerja UKM. J. Ekon. Bisnis. Vol 15 (2). 152-158 
pp. doi
http://dx.doi.org/10.35760/eb.2010.v15i2.331

Taufik, R. 2017. Perancangan Corporate Identity Arstudio Di Bandung. J. Sketsa. Vol 4 (2). 41-52 pp.[Online]. Available: https://ejournal.bsi.ac.id/ejurnal/index.ph p/sketsa/article/download/3392/2138.

Wiryawan, B. 2008. Kamus Brand. Jakarta: Red \& White Publishing. 